\title{
Phosphorylated mTOR is associated to androgen receptor expression in early triple-negative breast cancer
}

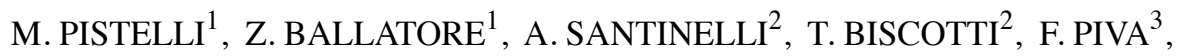 \\ G. OCCHIPINTI ${ }^{3}$, A. DELLA MORA ${ }^{1}$, A. PAGLIACCI ${ }^{1}$, N. BATTELLI $^{1}$, L. BASTIANELLI ${ }^{1}$, \\ M. DE LISA ${ }^{1}$, R. BRACCI ${ }^{1}$, E. MACCARONI ${ }^{1}$, R. BERARDI ${ }^{1}$ and S. CASCINU $^{1}$ \\ Departments of ${ }^{1}$ Medical Oncology, and ${ }^{2}$ Pathology, AOU Ospedali Riuniti, Università Politecnica delle Marche, Ancona; \\ ${ }^{3}$ Department of Specialistic Clinical and Odontostomatological Sciences, Polytechnic University of Marche, Ancona, Italy
}

Received January 19, 2016; Accepted February 24, 2016

DOI: $10.3892 /$ or.2016.4903

\begin{abstract}
The significance of phosphorylated mTOR (p-mTOR) expression is unknown in triple-negative breast carcinoma (TNBC). The aims of the present study were to assess the expression of p-mTOR in early TNBC and to evaluate possible correlations between androgen receptor (AR) expression, clinicopathological parameters and disease outcome. Between January 2009 and December 2013, all consecutive patients who were diagnosed and completed the treatment of invasive TNBC at our institution were eligible for this analysis. Patients with stage IV disease were excluded. The evaluation of p-mTOR immunohistochemical staining was semi-quantitatively considering both the percentage of positive tumor cells (range, $0-100 \%$ ) and staining intensity (range, 0-3+). Ninety-eight TNBC patients were included. Approximately $33 \%$ of cases were p-mTOR positive and there was no association between positive immunostaining for $\mathrm{p}$-mTOR and DFS $(\mathrm{P}=0.74)$ and $\mathrm{OS}(\mathrm{P}=0.81)$. $\mathrm{p}$-mTOR positivity was associated with small tumor size $(\mathrm{P}=0.03)$ and AR expression $(\mathrm{P}=0.04)$. High expression of $\mathrm{p}$-mTOR may drive tumor proliferation in almost one third of TNBC. The biological association between mTOR activation and AR pathway suggests that there may exist a subgroup of TNBC in which the combination of both AR antagonism and mTOR inhibition should have a synergistic effect on cell growth and tumor progression.
\end{abstract}

\section{Introduction}

Triple-negative breast cancers (TNBC) account for approximately $15-25 \%$ of all breast cancer. They are characterized

Correspondence to: Dr Mirco Pistelli, Clinica di Oncologia Medica, AO Ospedali Riuniti-Ancona, Università Politecnica delle Marche, Ancona, Italy

E-mail: mirco.pistelli@alice.it

Key words: triple-negative, breast cancer, mTOR, androgen receptor, prognosis by the lack of expression of estrogen, progesterone receptors $(\mathrm{ER} / \mathrm{PgR})$ and human epidermal growth factor receptor 2 (HER2) and by an aggressive clinical course with higher rates of relapse and poor overall survival in metastatic disease (1-3). Treatment options for patients with TNBC are limited due to the absence of hormone receptors and HER2; therefore, cytotoxic chemotherapy currently remains the only available treatment (4).

Given these characteristics, TNBC is a challenge in clinical practice.

Several studies demonstrated that a subgroup of TNBC patients displayed a remarkable sensitivity to chemotherapeutic agents. Between 17 and 58\% of TNBC patients have been shown to achieve pathological complete response (pCR) after anthracycline/platinum-based neoadjuvant chemotherapy and these patients had an excellent prognosis. On the contrary, those who failed to achieve a pCR had an exceptionally poor outcome $(5,6)$. Over the past decades there have been several attempts to use genomic data in order to explain the highly variable responses to therapy and clinical outcome of this setting of patients. Recently, genomic analyses have provided additional insights, showing a wide heterogeneity of molecular characteristics of TNBCs by gene expression profile. On this basis, Lehmann et al (7) identified six different TNBC subtypes including basal-like (type 1 and 2), immunomodulatory, mesenchymal, mesenchymal stem like and luminal androgen receptor subtype demonstrating the heterogeneity of TNBC.

Ongoing research into the molecular and genetic mechanisms of TNBC tumorigenesis are helping to find out processes involved in local tumor progression and distant metastases.

One of the most important mechanisms involved in the control of neoplastic transformation is the PI3K/Akt/mTOR pathway. The aberrant activation of this cascade seems to be of great importance in breast cancer. In addition, a high activation level of the PI3K/Akt/mTOR pathway has been related to worse prognosis and resistance to conventional chemotherapy.

The mammalian target of rapamycin (mTOR) is an important serine/threonine protein kinase of the phosphoinositide 3-kinase (PI3K)-related kinase family, which functions as an environmental sensor and regulates organismal growth, cell physiology and homeostasis. mTOR is the catalytic 
subunit of two distinct complexes, mTOR complex 1 and mTOR complex 2 (mTORC1 and mTORC2), which consist of several additional regulatory proteins. The subunit composition of each mTORC dictates its substrate specificity. Main substrates of mTORC1 are S6 kinase 1 (S6KB1) and eIF4Ebinding protein 1 (4E-BP1), both implicated in the regulation of mRNA and protein synthesis. mTORC2 controls several members of kinases including Akt and is thereby implicated in the regulation of cell survival, cell cycle progression and anabolism $(8,9)$.

Previous in vitro studies showed that phosphorylated mTOR (p-mTOR), the activate form is closely related with the active status of mTOR and the cell proliferative capacity $(10,11)$.

p-mTOR was found more frequently expressed in triplenegative than non-TNBC, suggesting that mTOR may play a crucial role in the molecular biology of TNBC. Besides, emerging preclinical evidence suggested that TNBC cells seem particularly sensitive to mTOR inhibitors, especially the androgen receptor-positive $\left(\mathrm{AR}^{+}\right) \mathrm{TNBC}$ cell lines, opening the possibility for the incorporation of target agents in treatments (12-15).

The aims of the present study were to assess the expression of the activated form p-mTOR in early TNBC and to evaluate possible correlations between immunohistochemical AR expression, clinicopathological parameters and disease outcome.

\section{Patients and methods}

Eligibility criteria. Between January 2009 and December 2013, all consecutive patients who were diagnosed and had completed the treatment of invasive TNBC at our institution were eligible for this analysis.

The study obtained the necessary approval by the Department of Medical Oncology, AO Ospedali Riuniti, Ancona. According to Italian legislation, since it was a retrospective study, with no direct patient involvement, ethical approval and patients consent for the study were not required (Official Gazette no. 72 of March 26, 2012). Patients with stage IV disease or with ductal carcinoma in situ with or without micro-invasion and patients with lack of information on pathologic or laboratory results were excluded. We analysed several parameters: clinical (age, performance status, type of surgery and adjuvant chemotherapy), pathological (tumor size, grading, necrosis, lymph nodes status, tumor histology, Ki-67 and lympho-vascular invasion) and molecular (AR and p-mTOR).

Immunohistochemistry. IHC analysis was performed on formalin-fixed, paraffin-embedded breast cancer tissue. The detection of antigens occurred automatically with Dako PT Link using EnVision ${ }^{\mathrm{TM}}$ FLEX Target Retrieval Solution High and Low $\mathrm{pH}(50 \mathrm{x})$ at $98^{\circ} \mathrm{C}$.

After treatment with $3 \%$ hydrogen peroxide solution for 10 min to block endogenous peroxidase, the sections were incubated with primary antibody: ER (clone 1D5, 1:30; Dako, Carpinteria, CA, USA), PR (clone PgR636, 1:50; Dako), Ki-67 (clone MIB-1, 1:80; Dako), HER2/neu (HercepTest RTU; Dako), AR (clone F39.4.1, 1:60; BioGenex, San Ramon, CA, USA) and phospho-mTOR (Ser2448) (clone 49F9, 1:50; Cell

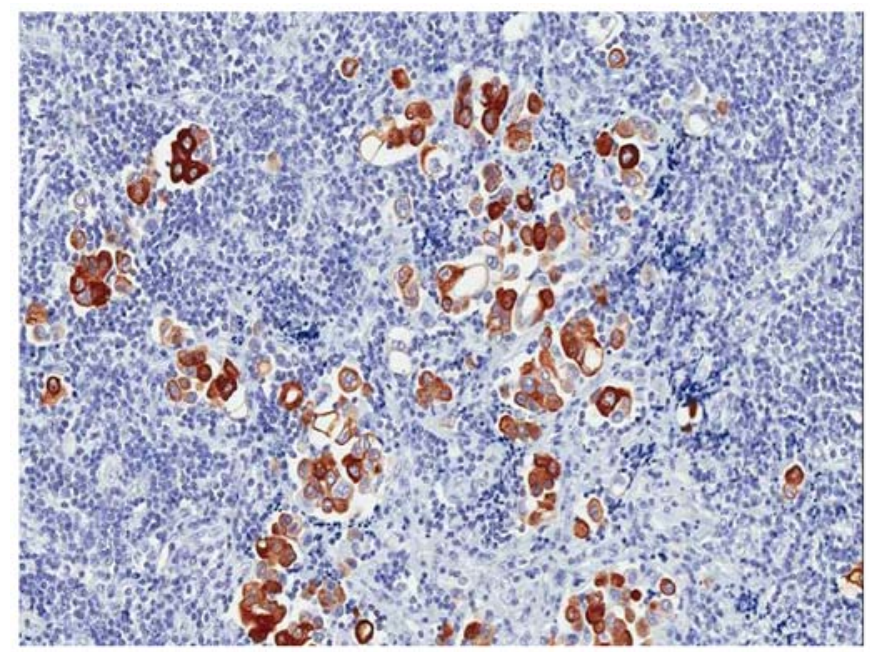

Figure 1. Cytoplasmic immunostaining of p-mTOR in TNBC cells (original magnification, $\mathrm{x} 10)$.

Signaling Technology Inc., Beverly, MA, USA). The staining was completed using EnVision FLEX ${ }^{\mathrm{TM}} / \mathrm{HRP}$ (Dako) as detection system; 3,3-diaminobenzidine-hydrogen peroxide was used as chromogen. IHC was performed using an autostaining system (Autostainer Link 48; Dako).

For ER, PR, Ki-67 and AR the percentage of positive nuclei was evaluated by counting 5,000 neoplastic cells in different areas of the neoplasia (16).

For Ki-67, the count was performed in the peripheral part of the neoplasia (i.e. the most proliferating part). The staining intensity was not considered. The values were expressed as continuous variable, and ranging from 0 to $100 \%$. Immunostaining for p-mTOR was semi-quantitatively assessed by considering both the percentage of positive neoplastic cells (range, 0-100\%), and the strongest staining intensity (range, $0-3+$; 0 , no staining, $1+$, weak, $2+$, moderate; $3+$, strong) (Fig. 1). Also a 'score of positivity' was calculated by multiplying the value of the percentage of positive neoplastic cells for the value of staining intensity (range, 0-300). HER-2 status was evaluated using a semi-quantitative score (0-3+); patients with 2+ IHC staining for HER2 underwent fluorescence in situ hybridization to determine HER2 status (17). The evaluation of the above immunohistochemical staining was carried out, with a double-blind method, by two experienced pathologists, they were not aware of any clinical data of patients, including follow-up and status.

Statistical analysis. Disease-free survival (DFS) was defined as the interval between the date of diagnosis of TNBC to the first failure (including loco-regional and/or distant relapse, second primary or death). Overall survival (OS) was calculated from the date of diagnosis to the date of the last follow-up visit or death. Patients who were not reported to be dead at the time of the analysis were censored at the date they were last known to be alive. Survival distribution was estimated by the Kaplan-Meier method. Subgroup differences were estimated by Chi-square test. The Cox multivariate proportional hazard regression model was used to evaluate the prognostic factors on disease-free survival 
Table I. Baseline characteristics of 98 TNBC patients based on p-mTOR expression.

\begin{tabular}{|c|c|c|c|c|}
\hline Characteristics & $\begin{array}{c}\text { Total } \\
\text { no. of patients }(\%)\end{array}$ & $\begin{array}{l}\text { p-mTOR negativity } \\
\text { no. of patients }(\%)\end{array}$ & $\begin{array}{l}\text { p-mTOR positivity } \\
\text { no. of patients }(\%)\end{array}$ & P-value \\
\hline \multicolumn{5}{|l|}{ Age (years) } \\
\hline$\leq 50$ & 46 (46.9) & $31(31.6)$ & $15(15.3)$ & \multirow[t]{2}{*}{0.83} \\
\hline$>50$ & $52(53.1)$ & $35(35.8)$ & $17(17.3)$ & \\
\hline \multicolumn{5}{|l|}{ Menopausal status } \\
\hline Yes & $45(45.9)$ & $30(30.6)$ & $15(15.3)$ & \multirow[t]{2}{*}{0.93} \\
\hline No & $53(54.1)$ & $36(36.8)$ & $17(17.3)$ & \\
\hline \multicolumn{5}{|l|}{ Tumor size } \\
\hline pT1 & $56(57.1)$ & $33(33.7)$ & $23(23.4)$ & \multirow[t]{3}{*}{$\mathbf{0 . 0 3}$} \\
\hline pT2 & $41(41.8)$ & $32(32.6)$ & $9(9.2)$ & \\
\hline pT3-T4 & $1(1.1)$ & $1(1.1)$ & $0(0)$ & \\
\hline \multicolumn{5}{|c|}{ Lymph node status (pN) } \\
\hline pNO & $58(59.1)$ & $41(41.8)$ & $17(17.3)$ & \multirow[t]{2}{*}{0.52} \\
\hline $\mathrm{pN}^{+}$ & $40(40.9)$ & $25(25.6)$ & $15(15.3)$ & \\
\hline \multicolumn{5}{|l|}{ Histological type } \\
\hline Ductal carcinoma & $95(96.9)$ & $64(65.4)$ & $31(31.5)$ & \multirow[t]{3}{*}{0.21} \\
\hline Lobular carcinoma & $1(1.1)$ & 0 & $1(1.1)$ & \\
\hline Other & $2(2.0)$ & $2(2.0)$ & $0(0)$ & \\
\hline \multicolumn{5}{|c|}{ Lymphovascular invasion } \\
\hline No & $72(73.5)$ & $52(53.1)$ & $20(20.4)$ & \multirow[t]{2}{*}{0.14} \\
\hline Yes & $26(26.5)$ & $14(14.3)$ & $12(12.2)$ & \\
\hline \multicolumn{5}{|l|}{ Necrosis } \\
\hline No & $81(82.7)$ & $55(56.2)$ & $26(26.5)$ & \multirow[t]{2}{*}{0.97} \\
\hline Yes & $17(17.3)$ & $11(11.2)$ & $6(6.1)$ & \\
\hline \multicolumn{5}{|l|}{ AR } \\
\hline Negative & $80(81.6)$ & $58(59.2)$ & $22(22.4)$ & \multirow[t]{2}{*}{0.04} \\
\hline Positive & $18(18.4)$ & $8(8.2)$ & $10(10.2)$ & \\
\hline \multicolumn{5}{|l|}{ Recurrences } \\
\hline No & $76(77.6)$ & $52(53.1)$ & $24(24.5)$ & \multirow[t]{2}{*}{0.87} \\
\hline Yes & $22(22.4)$ & $14(14.3)$ & $8(8.1)$ & \\
\hline \multicolumn{5}{|l|}{ Deaths } \\
\hline No & $81(82.7)$ & $55(56.2)$ & $26(26.5)$ & \multirow[t]{2}{*}{0.97} \\
\hline Yes & $17(17.3)$ & $11(11.2)$ & $6(6.1)$ & \\
\hline Total & 98 (100) & $66(67.4)$ & $32(32.6)$ & \\
\hline
\end{tabular}

(DFS) and overall survival (OS). Significant differences in probability of surviving between the data were evaluated by log-rank test. Hazard ratios and $95 \%$ confidence intervals (CIs) were estimated from regression coefficients. A significance level of 0.05 was chosen to assess the statistical significance. Statistical analysis was performed with the MedCalc package (MedCalc ${ }^{\circledR}$ v9.4.2.0; MedCalc Software, Ostend, Belgium).

\section{Results}

Clinicopathological characteristics. Ninety-eight TNBC patients were included in our analysis. Clinicopathological characteristics are summarized in Table I. Median age was 52 years (range 26-83 years) and the majority of patients (79.6\%) underwent breast conservative surgery.

Most patients (57.1\%) presented pT1 tumors (up to $2 \mathrm{~cm}$ in size). Lymph nodes were disease-positive in $40.9 \%$ of cases. Patients $(95.9 \%)$ received an adjuvant chemotherapy while $12.2 \%$ of them underwent neo-adjuvant treatment.

The mean follow-up time was 4.7 years $(0.65-8.3$ years). The median DFS was 4.9 years (range, $0.18-8.35$ ) and the median OS was 5.1 years (range, 0.65-8.3). All tumors were grade 3 and with a high proliferating index (Ki-67 >20\%). Lympho-vascular invasion and necrosis were reported in $26(26.5 \%)$ and 17 cases (17.3), respectively. The androgen receptor expression was reported in 18 cases $(18.4 \%)$ and the p-mTOR was positive in 32 cases $(32.6 \%)$. P-mTOR was 


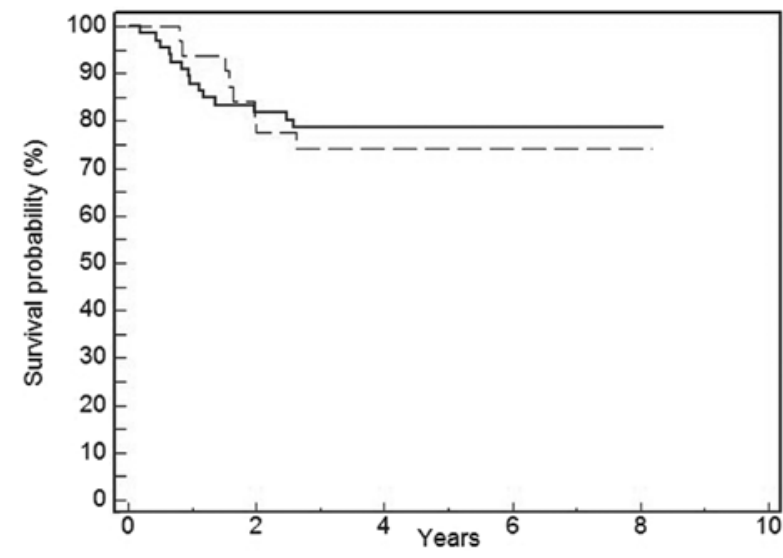

Figure 2. Kaplan-Meier DFS curves for TNBC patients according to p-mTOR positivity (continuous line) and p-mTOR negativity (dashed line).

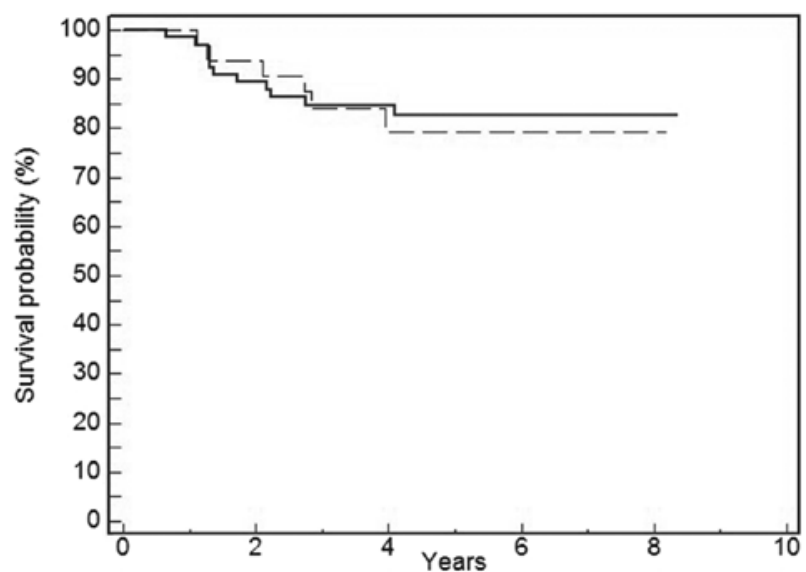

Figure 3. Kaplan-Meier OS curves for TNBC patients according to p-mTOR positivity (continuous line) and p-mTOR negativity (dashed line).

located exclusively in the cytoplasm and its expression did not correlate with any of the following clinicopathological features investigated (Table I). Notably, p-mTOR positivity was associated with small tumor size $(\mathrm{P}=0.03)$ and $\mathrm{AR}$ expression $(\mathrm{P}=0.04)$.

Univariate survival analysis revealed that positive immunostaining for $\mathrm{p}-\mathrm{mTOR}$ was not associated with DFS $(\mathrm{P}=0.74)$ (Fig. 2) and OS (P=0.81) (Fig. 3). Tumor size $(\mathrm{P}=0.03)$ and lymph node involvement $(\mathrm{P}=0.03)$ were significantly related to worse DFS and OS (Tables II and III).

Multivariate analysis confirmed that tumor size was the only significant independent prognostic variable influencing both DFS and OS $(\mathrm{P}=0.05$ and $\mathrm{P}=0.03$, respectively) while lymph node involvement influenced only OS $(\mathrm{P}=0.05)$.

\section{Discussion}

The PI3K/Akt/mTOR pathway regulates several cellular functions such as cell growth, survival and proliferation, characterizing tumorigenesis as well as tumor progression (18). In breast cancer, a high activation level of the PI3K/Akt/mTOR pathway has been related to resistance to conventional chemo and endocrine therapy. The recent BOLERO-2 trial comparing everolimus plus exemestane vs. placebo plus exemestane in
Table II. Univariate and multivariate analysis of sample features and DFS.

\begin{tabular}{|c|c|c|c|c|}
\hline \multirow[b]{2}{*}{ Parameters } & \multirow{2}{*}{$\begin{array}{l}\text { Univariate } \\
\text { analysis } \\
\text { P-value }\end{array}$} & \multicolumn{3}{|c|}{ Multivariate analysis } \\
\hline & & HR & $95 \% \mathrm{CI}$ & P-value \\
\hline $\begin{array}{l}\text { Age (years) } \\
\leq 50 \text { vs. }>50\end{array}$ & 0.91 & & & \\
\hline $\begin{array}{l}\text { Tumor size }(\mathrm{cm}) \\
\leq 2 \text { vs. }>2\end{array}$ & 0.03 & 2.39 & $0.97-5.86$ & 0.05 \\
\hline $\begin{array}{l}\text { Lymph node status } \\
\text { pN0 vs. } \mathrm{pN}^{+}\end{array}$ & 0.04 & 2.25 & $0.96-5.25$ & 0.06 \\
\hline $\begin{array}{l}\text { Lympho-vascular } \\
\text { invasion } \\
\text { Negative vs. positive }\end{array}$ & 0.18 & & & \\
\hline $\begin{array}{l}\text { Necrosis } \\
\text { Negative vs. positive }\end{array}$ & 0.52 & & & \\
\hline $\begin{array}{l}\text { AR expression } \\
\leq 10 \text { vs. }>10\end{array}$ & 0.49 & & & \\
\hline $\begin{array}{l}\text { p-mTOR } \\
\text { Negative vs. positive }\end{array}$ & 0.74 & & & \\
\hline
\end{tabular}

Table III. Univariate and multivariate analysis of sample features and OS.

\begin{tabular}{|c|c|c|c|c|}
\hline \multirow[b]{2}{*}{ Parameters } & \multirow{2}{*}{$\begin{array}{c}\begin{array}{c}\text { Univariate } \\
\text { analysis }\end{array} \\
\text { P-value }\end{array}$} & \multicolumn{3}{|c|}{ Multivariate analysis } \\
\hline & & HR & $95 \% \mathrm{CI}$ & P-value \\
\hline $\begin{array}{l}\text { Age (years) } \\
\leq 50 \text { vs. }>50\end{array}$ & 0.64 & & & \\
\hline $\begin{array}{l}\text { Tumor size }(\mathrm{cm}) \\
\leq 2 \text { vs. }>2\end{array}$ & 0.01 & 3.48 & $1.13-10.67$ & $\mathbf{0 . 0 3}$ \\
\hline $\begin{array}{l}\text { Lymph node status } \\
\text { pN0 vs. } \mathrm{pN}^{+}\end{array}$ & 0.02 & 2.63 & $0.97-7.12$ & 0.05 \\
\hline $\begin{array}{l}\text { Lympho-vascular } \\
\text { invasion } \\
\text { Negative vs. positive }\end{array}$ & 0.11 & & & \\
\hline $\begin{array}{l}\text { Necrosis } \\
\text { Negative vs. positive }\end{array}$ & 0.14 & & & \\
\hline $\begin{array}{l}\text { AR expression } \\
\leq 10 \text { vs. }>10\end{array}$ & 0.39 & & & \\
\hline $\begin{array}{l}\text { p-mTOR } \\
\text { Negative vs. positive }\end{array}$ & 0.95 & & & \\
\hline
\end{tabular}

women with resistance to no-steroidal aromatase inhibitors demonstrated a 6-month improvement in progression-free survival leading to the approval for the treatment of ER-positive metastatic breast cancer.

Previous in vitro studies showed that p-mTOR correlated with the activation of mTOR and an increase in prolif- 


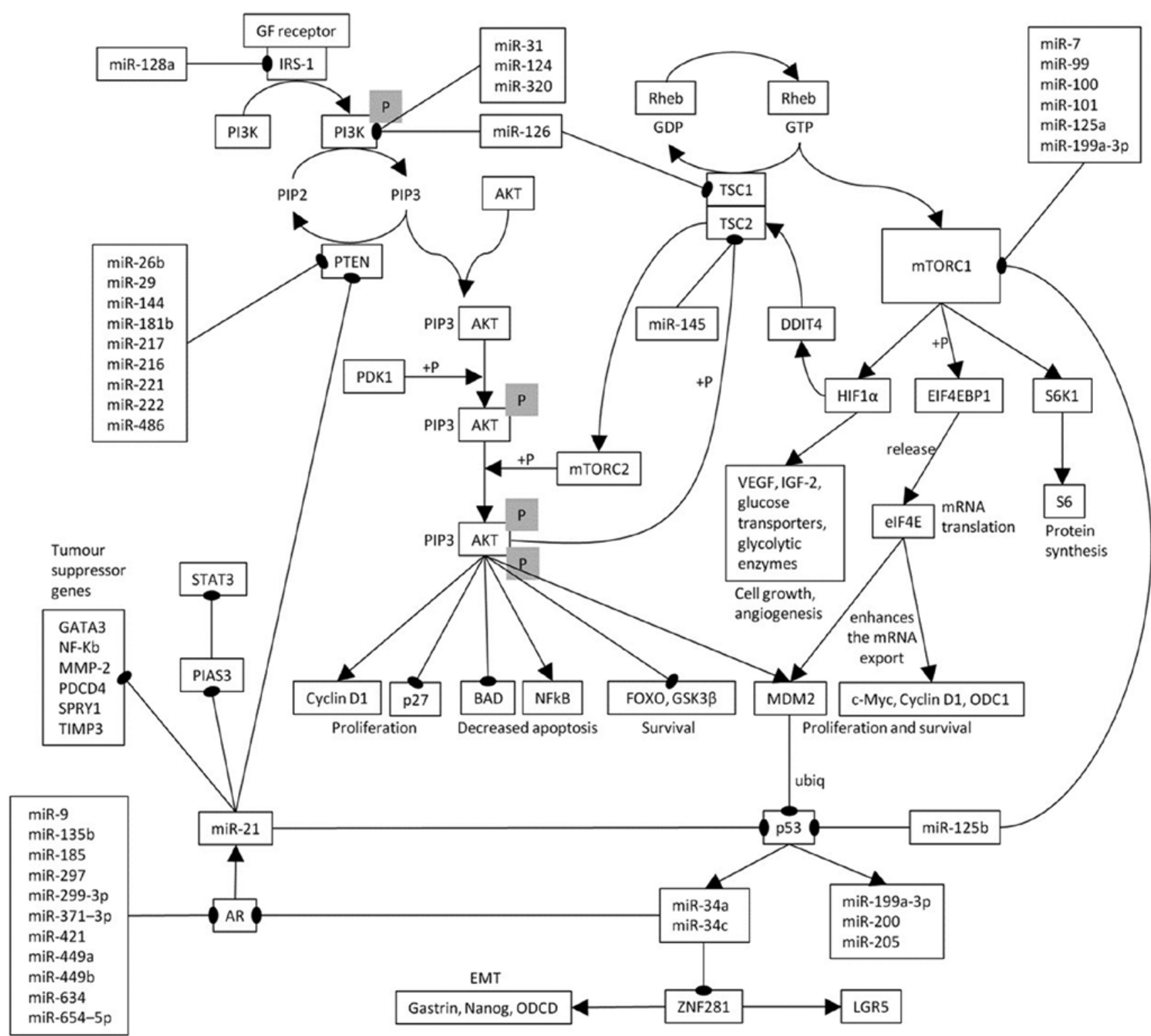

Figure 4. The pathway that links mTORC1 to AR is shown. Arrows, activation, the connectors ending with thick point represent inhibition. RPS6KB1, ribosomal protein S6 kinase, $70 \mathrm{kDa}$, polypeptide; $1 \mathrm{RPS6}$, ribosomal protein S6; EIF4EBP1, eukaryotic translation initiation factor 4E binding protein 1; EIF4E, eukaryotic translation initiation factor 4E; HIF1A, hypoxia inducible factor 1, $\alpha$ subunit; VEGF, vascular endothelial growth factor genes; DDIT4, DNA-damage-inducible transcript 4; 14-3-3; tyrosine 3-monooxygenase/tryptophan 5-monooxygenase activation protein; TSC1, tuberous sclerosis 1; TSC2, tuberous sclerosis 2; NBN, nibrin; MDM2, MDM2 proto-oncogene; E3, ubiquitin protein ligase; ODC1, ornithine decarboxylase 1; AR, androgen receptor; PIAS3, protein inhibitor of activated STAT3; PTEN, phosphatase and tensin homolog; PIP3, phosphatidylinositol $(3,4,5)$-trisphosphate; ubiq, ubiquitination; $+\mathrm{P}$, phosphorylation.

eration $(10,19)$. In the present study, the high expression of the active form of mTOR (p-mTOR) was present in almost one third of TNBC, suggesting that aberrant activation of the PI3K/Akt/mTOR may drive tumor proliferation in this subtype of breast cancer. Although there are no therapeutic evidence using mTOR inhibitors in TNBC, these data may open new therapeutic scenarios, also suggested by in vitro and in vivo assays, in which mTOR inhibitors demonstrated antitumor activity in TNBC respectively in cell lines and mouse xenograft models $(18,20,21)$ indicating $\mathrm{mTOR}$ as the potential target.

Three reports have previously been published on the expression of p-mTOR in breast cancer; Bose et al (22) found increased levels of p-mTOR in high grade vs. low grade cancers. However, Zhou et al (13) found no relationship between p-mTOR and tumor grade. Recently Walsh et al (12) showed a high expression of p-mTOR in $\sim 36 \%$ of triple-negative breast carcinomas; this result is consistent with the present study. Furthermore, they revealed that p-mTOR was significantly more frequently expressed in triple-negative than non-triple negative diseases, suggesting that inhibitors directed against this protein may be effective in at least some patients affected by this subtype of breast cancer.

In our results, $32.6 \%$ of cases were p-mTOR positive and its high expression was not related to the considered clinicopathological features neither to DFS and OS at the univariate and multivariate survival analysis. However, in patients who had small tumor size and early stage, p-mTOR 
positivity was significantly higher and that is consistent with a previous study (13). Of interest, the present investigation is the first clinical retrospective study showing the strong correlation between $\mathrm{p}-\mathrm{mTOR}$ immunostaining and AR positivity in a subgroup of TNBC. It is consistent with other reports and it confirms microarray analysis recently conducted on TNBC (23).

A spectrum of somatic mutations have been discovered in TNBC; mutations in PIK3CA (10.2\%), the gene that encodes the p1 $10 \alpha$ catalytic subunit of phosphatidylinositol-3 kinase $(\mathrm{PI} 3 \mathrm{~K})$ are the most common. Lehmann et al $(23,24)$ observed that all AR-positive $\left(\mathrm{AR}^{+}\right) \mathrm{TNBC}$ cell lines contain the PIK3CA mutation (H1047R) and are highly sensitive to the PI3K/mTOR inhibitor NVP-BEZ235, suggesting that combination of $\mathrm{AR}$ antagonism and $\mathrm{PI} 3 \mathrm{~K}$ inhibition may have a synergistic effect on $\mathrm{AR}^{+} \mathrm{TNBC}$ cell growth. Collectively, these findings are similar with other reports (1) and consistent with observations that hormonally responsive cancers, such as those expressing ER and AR are more likely to acquire PIK3CA mutations (24).

Up to date, in BC AR expression and relation with the PI3K pathway were studied in cell lines or xenograft models and the exact mechanism of action of AR in TNBC is still controversial (1,24-26). Due to the uncertain biological significance of the relationship between mTOR and AR, we defined the regulation pathway linking mTOR with AR by means of literature analysis and referring to Reactome (www.reactome.org) and KEGG databases (http://www.genome.jp/kegg/pathway.html).

The relationship between AR expression and the mTOR pathway could be explained by inherent biological data from literature analysis (Fig. 4). It should be noted that miR-21 and miR-34a, key elements of our pathway, were shown to be expressed in TNBC $(20,26,27,28)$. In fact, there are many modifier pathways, specifically GTPase activating proteins TSC 1 and TSC 2 are negative regulators of mTORC 1 and positive regulators of mTORC2 (29). These proteins act on Rheb GTPase hydrolyzing the GTP converting it to Rheb-GDP complex. Rheb is activated bound to GTP and turned off when bound with GDP, so respectively triggering or defusing mTORC1. Activated mTORC1, by phosphorylating some downstream effectors, gives rise to an increased protein translation and autophagy inhibition. In particular, it activates RPS6KB1 kinase that, by phosphorylating RPS6, induces cell growth and proliferation. Moreover, mTORC1 phosphorylates EIF4EBP1 that releases eIF4E so activating the translation of various mRNAs including HIF1A. This is the $\alpha$ subunit of a transcription factor that, in response to hypoxia, activates transcription of genes involved in regulation of erythropoiesis, angiogenesis, vascular tone, matrix metabolism, glucose metabolism, cell proliferation and survival, apoptosis (VEDF, IGF-2 and EPO) (30). Moreover, HIF1A induces DDIT4 transcription that, through the dissociation of 14-3-3 inhibitory protein from TSC2 (31), activates TSC2 that in turn inhibits mTORC1. eIF4E not only plays a key role in translation, but also in the nucleus where it promotes the export of specific mRNAs, as c-myc, Mdm2, NBN, ornithine decarboxylase (ODC1), and cyclin D1, that support proliferative and survival signalling pathways (32-34). MDM2, by ubiquitination, leads to $\mathrm{p} 53$ transcription factor degradation by the proteasome and, in turn, to miR-34 family repression, the latter is a direct transcriptional target of p53 (35) and the miR-34 silencing is frequent in several tumors, including breast cancer, and correlates with metastasis and poor survival (36). Since miR-34a/c can regulate AR (37), miR-34 repression causes lack of AR inhibition. AR promotes miR-21 transcription by some androgen responsive elements (AREs) in miR-21 promoter (in particular, three binding sites are known: ARE1 and ARE2/3 (38,39). The oncogene miR-21 indirectly suppresses p53 with a feedback loop mechanism (40) and downregulates some tumor suppressor genes, including PIAS3 (41), giving rise also to STAT3 upregulation. Furthermore, miR-21 blocks PTEN (42-44), the phosphatidylinositol-3,4,5-trisphosphate 3-phosphatase that dephosphorylates PIP3 to PIP2 negatively regulating AKT/mTORC1 signalling pathway. This pathway analyses demonstrates a correlation between activated mTORC1 and AR expression, of which the key elements are p53, miR-21 and miR-34. Therefore, low level of activated mTORC1 yields low AR expression.

It seems that some microRNAs are deregulated in TNBC. Particularly, miR-21 and miR-34a were significantly overexpressed in breast cancer, but miR-21 was significantly overexpressed in TNBC vs. non-TNBC, moreover, it seems to be associated to occurrence of lymph node metastases (27).

Other authors showed that miR-185 was strongly downregulated in TNBC tissues and its ectopic expression suppressed tumor proliferation, directly targeting DNMT1 and E2F6 (45). We can suggest that miR-185 acts also by suppressing AR. Another study showed miR-126 downregulation (46) and, according to our pattern, this should increase AKT/mTORC1 activation by targeting PI3K but, on the contrary, reducing mTORC1 by its target TSC2. Instead miR-145 downregulation (46) should ameliorate prognosis by TSC2 restoration and so mTORC1 reduction. It is interesting that miR-101 and miR-125a were associated to metastasis (46) instead we show that they should block mTORC1. The evidence that miR-31 downregulation causes an enhancement in metastasis (47) can be explained because it is an AKT inhibitor. The highly migratory and metastatic characteristics of TNBC with low miR-200 family expression (48) can be due to the inferred p53 low levels. The fact that miR-205 is downregulated but $\mathrm{miR}-200 \mathrm{a} / \mathrm{b} / \mathrm{c}$ is upregulated (46) cannot be realized by our pathway. Certainly their regulation is much more complex than that shown here and much remains to be clarified. However, this pathway can be useful also to plan new experiments.

All these complex results and analyses suggested that a high expression of the active form of mTOR (p-mTOR) and consequently an aberrant activation of the PI3K/Akt/mTOR pathway may drive tumor proliferation and that is true for almost one third of TNBC. Currently, TNBC is a subset of breast cancer with no available targeted therapies and hence adverse clinical outcome. Those findings could provide important information as to the potential opportunity for novel targeted and personalized treatment for these women but further translational investigations regarding the therapeutic efficacy of mTOR inhibitors in TNBC are required. Our analysis also confirms the biological association between mTOR activation and AR pathway, suggesting that may exist a subgroup of TNBC in which the combination of both AR antagonism and mTOR inhibition should have a synergistic effect on cell growth and tumor progression. 


\section{References}

1. Cuenca-López MD, Montero JC, Morales JC, Prat A, Pandiella A and Ocana A: Phospho-kinase profile of triple negative breast cancer and androgen receptor signaling. BMC Cancer 14: 302, 2014.

2. Dent R, Trudeau M, Pritchard KI, Hanna WM, Kahn HK, Sawka CA, Lickley LA, Rawlinson E, Sun P and Narod SA: Triple-negative breast cancer: Clinical features and patterns of recurrence. Clin Cancer Res 13: 4429-4434, 2007.

3. Liedtke C, Mazouni C, Hess KR, André F, Tordai A, Mejia JA Symmans WF, Gonzalez-Angulo AM, Hennessy B, Green M, et al: Response to neoadjuvant therapy and long-term survival in patients with triple-negative breast cancer. J Clin Oncol 26: 1275-1281, 2008.

4. Craig DW, O'Shaughnessy JA, Kiefer JA, Aldrich J, Sinari S, Moses TM, Wong S, Dinh J, Christoforides A, Blum JL, et al: Genome and transcriptome sequencing in prospective metastatic triple-negative breast cancer uncovers therapeutic vulnerabilities. Mol Cancer Ther 12: 104-116, 2013.

5. Pal SK, Childs BH and Pegram M: Triple negative breast cancer: Unmet medical needs. Breast Cancer Res Treat 125: 627-636, 2011.

6. André F and Zielinski CC: Optimal strategies for the treatment of metastatic triple-negative breast cancer with currently approved agents. Ann Oncol 23 (Suppl 6): vi46-vi51, 2012.

7. Lehmann BD and Pietenpol JA: Identification and use of biomarkers in treatment strategies for triple-negative breast cancer subtypes. J Pathol 232: 142-150, 2014.

8. Laplante M and Sabatini DM: mTOR signaling in growth control and disease. Cell 149: 274-293, 2012.

9. Dann SG, Selvaraj A and Thomas G: mTOR Complex1-S6K1 signaling: At the crossroads of obesity, diabetes and cancer. Trends Mol Med 13: 252-259, 2007.

10. Yaba A, Bianchi V, Borini A and Johnson J: A putative mitotic checkpoint dependent on mTOR function controls cell proliferation and survival in ovarian granulosa cells. Reprod Sci 15 128-138, 2008

11. Vazquez-Martin A, Oliveras-Ferraros C, Bernadó L, LópezBonet $\mathrm{E}$ and Menendez JA: The serine 2481-autophosphorylated form of mammalian target of rapamycin (mTOR) is localized to midzone and midbody in dividing cancer cells. Biochem Biophys Res Commun 380: 638-643, 2009.

12. Walsh S, Flanagan L, Quinn C, Evoy D, McDermott EW, Pierce A and Duffy MJ: mTOR in breast cancer: Differential expression in triple-negative and non-triple-negative tumors. Breast 21: 178-182, 2012.

13. Zhou X, Tan M, Stone Hawthorne V, Klos KS, Lan KH, Yang Y, Yang W, Smith TL, Shi D and Yu D: Activation of the Akt/ mammalian target of rapamycin/4E-BP1 pathway by ErbB2 overexpression predicts tumor progression in breast cancers. Clin Cancer Res 10: 6779-6788, 2004.

14. Ueng SH, Chen SC, Chang YS, Hsueh S, Lin YC, Chien HP, Lo YF, Shen SC and Hsueh C: Phosphorylated mTOR expression correlates with poor outcome in early-stage triple negative breast carcinomas. Int J Clin Exp Pathol 5: 806-813, 2012.

15. Shaw RJ and Cantley LC: Ras, PI(3)K and mTOR signalling controls tumour cell growth. Nature 441: 424-430, 2006.

16. Hammond ME, Hayes DF, Dowsett M, Allred DC, Hagerty KL, Badve S, Fitzgibbons PL, Francis G, Goldstein NS, Hayes M, et al: American Society of Clinical Oncology/College Of American Pathologists guideline recommendations for immunohistochemical testing of estrogen and progesterone receptors in breast cancer. J Clin Oncol 28: 2784-2795, 2010.

17. Wolff AC, Hammond ME, Hicks DG, Dowsett M, McShane LM, Allison KH, Allred DC, Bartlett JM, Bilous M, Fitzgibbons P, et al; American Society of Clinical Oncology; College of American Pathologists: Recommendations for human epidermal growth factor receptor 2 testing in breast cancer: American Society of Clinical Oncology/College of American Pathologists clinical practice guideline update. J Clin Oncol 31: 3997-4013, 2013.

18. Yunokawa M,Koizumi F, Kitamura Y,Katanasaka Y, Okamoto N, Kodaira M, Yonemori K, Shimizu C, Ando M, Masutomi K, et al: Efficacy of everolimus, a novel mTOR inhibitor, against basal-like triple-negative breast cancer cells. Cancer Sci 103: $1665-1671,2012$.
19. Vazquez-Martin A, Oliveras-Ferraros C, Del Barco S, MartinCastillo B and Menendez JA: If mammalian target of metformin indirectly is mammalian target of rapamycin, then the insulinlike growth factor-1 receptor axis will audit the efficacy of metformin in cancer clinical trials. J Clin Oncol 27: e207-209; author reply e210, 2009.

20. Zhang H, Cohen AL, Krishnakumar S, Wapnir IL, Veeriah S, Deng G, Coram MA, Piskun CM, Longacre TA, Herrler M, et al: Patient-derived xenografts of triple-negative breast cancer reproduce molecular features of patient tumors and respond to mTOR inhibition. Breast Cancer Res 16: R36, 2014.

21. Xu S, Li S, Guo Z, Luo J, Ellis MJ and Ma CX: Combined targeting of mTOR and AKT is an effective strategy for basallike breast cancer in patient-derived xenograft models. Mol Cancer Ther 12: 1665-1675, 2013.

22. Bose S, Chandran S, Mirocha JM and Bose N: The Akt pathway in human breast cancer: a tissue-array-based analysis. Mod Pathol 19: 238-245, 2006.

23. Lehmann BD, Bauer JA, Schafer JM, Pendleton CS, Tang L, Johnson KC, Chen X, Balko JM, Gómez H, Arteaga CL, et al: PIK3CA mutations in androgen receptor-positive triple negative breast cancer confer sensitivity to the combination of PI3K and androgen receptor inhibitors. Breast Cancer Res 16: 406, 2014.

24. Lehmann BD, Bauer JA, Chen X, Sanders ME, Chakravarthy AB, Shyr Y and Pietenpol JA: Identification of human triple-negative breast cancer subtypes and preclinical models for selection of targeted therapies. J Clin Invest 121: 2750-2767, 2011.

25. Gucalp A and Traina TA: Triple-negative breast cancer: Role of the androgen receptor. Cancer J 16: 62-65, 2010.

26. Edlind MP and Hsieh AC: PI3K-AKT-mTOR signaling in prostate cancer progression and androgen deprivation therapy resistance. Asian J Androl 16: 378-386, 2014.

27. Dong G, Liang X, Wang D, Gao H, Wang L, Wang L, Liu J and Du Z: High expression of miR-21 in triple-negative breast cancers was correlated with a poor prognosis and promoted tumor cell in vitro proliferation. Med Oncol 31: 57, 2014.

28. Medimegh I, Omrane I, Privat M, Uhrhummer N, Ayari H, Belaiba F, Benayed F, Benromdhan K, Mader S, Bignon IJ, et al: MicroRNAs expression in triple negative vs non triple negative breast cancer in Tunisia: Interaction with clinical outcome. PLoS One 9: e111877, 2014.

29. Huang J, Dibble CC, Matsuzaki M and Manning BD: The TSC1-TSC2 complex is required for proper activation of mTOR complex 2. Mol Cell Biol 28: 4104-4115, 2008

30. Ke Q and Costa M: Hypoxia-inducible factor-1 (HIF-1). Mol Pharmacol 70: 1469-1480, 2006.

31. DeYoung MP, Horak P, Sofer A, Sgroi D and Ellisen LW: Hypoxia regulates TSC1/2-mTOR signaling and tumor suppression through REDD1-mediated 14-3-3 shuttling. Genes Dev 22: 239-251, 2008

32. Culjkovic B, Topisirovic I, Skrabanek L, Ruiz-Gutierrez M and Borden KL: eIF4E is a central node of an RNA regulon that governs cellular proliferation. J Cell Biol 175: 415-426, 2006.

33. Culjkovic-Kraljacic B, Baguet A, Volpon L, Amri A and Borden KL: The oncogene eIF4E reprograms the nuclear pore complex to promote mRNA export and oncogenic transformation. Cell Rep 2: 207-215, 2012.

34. Giulietti M, Milantoni SA, Armeni T, Principato G and Piva F: ExportAid: Database of RNA elements regulating nuclear RNA export in mammals. Bioinformatics 31: 246-251, 2015

35. Rokavec M, Li H, Jiang L and Hermeking H: The p53/miR-34 axis in development and disease. J Mol Cell Biol 6: 214-230, 2014.

36. Hermeking H: MicroRNAs in the 553 network: Micromanagement of tumour suppression. Nat Rev Cancer 12: 613-626, 2012.

37. Östling P, Leivonen SK, Aakula A, Kohonen P, Mäkelä R, Hagman Z, Edsjö A, Kangaspeska S, Edgren H, Nicorici D, et al: Systematic analysis of microRNAs targeting the androgen receptor in prostate cancer cells. Cancer Res 71: 1956-1967, 2011.

38. Ribas J, Ni X, Haffner M, Wentzel EA, Salmasi AH, Chowdhury WH, Kudrolli TA, Yegnasubramanian S, Luo J, Rodriguez R, et al: miR-21: An androgen receptor-regulated microRNA that promotes hormone-dependent and hormoneindependent prostate cancer growth. Cancer Res 69: 7165-7169, 2009.

39. Teng Y, Litchfield LM, Ivanova MM, Prough RA, Clark BJ and Klinge CM: Dehydroepiandrosterone-induces miR-21 transcription in HepG2 cells through estrogen receptor $\beta$ and androgen receptor. Mol Cell Endocrinol 392: 23-36, 2014. 
40. Ma X, Choudhury SN, Hua X, Dai Z and Li Y: Interaction of the oncogenic miR-21 microRNA and the p53 tumor suppressor pathway. Carcinogenesis 34: 1216-1223, 2013.

41. Xiong Q, Zhong Q, Zhang J, Yang M, Li C, Zheng P, Bi LJ and Ge F: Identification of novel miR-21 target proteins in multiple myeloma cells by quantitative proteomics. J Proteome Res 11: 2078-2090, 2012.

42. Meng F, Henson R, Wehbe-Janek H, Ghoshal K, Jacob ST and Patel T: MicroRNA-21 regulates expression of the PTEN tumor suppressor gene in human hepatocellular cancer. Gastroenterology 133: 647-658, 2007.

43. Bao B, Ali S, Kong D, Sarkar SH, Wang Z, Banerjee S, Aboukameel A, Padhye S, Philip PA and Sarkar FH: Anti-tumor activity of a novel compound-CDF is mediated by regulating miR-21, miR-200, and PTEN in pancreatic cancer. PLoS One 6: e17850, 2011.

44. Darido C, Georgy SR, Wilanowski T, Dworkin S, Auden A, Zhao Q, Rank G, Srivastava S, Finlay MJ, Papenfuss AT, et al: Targeting of the tumor suppressor GRHL3 by a miR21-dependent proto-oncogenic network results in PTEN loss and tumorigenesis. Cancer Cell 20: 635-648, 2011.
45. Tang H, Liu P, Yang L, Xie X, Ye F, Wu M, Liu X, Chen B, Zhang L and Xie X: miR-185 suppresses tumor proliferation by directly targeting E2F6 and DNMT1 and indirectly upregulating BRCA1 in triple-negative breast cancer. Mol Cancer Ther 13: 3185-3197, 2014.

46. Cascione L, Gasparini P, Lovat F, Carasi S, Pulvirenti A, Ferro A, Alder H, He G, Vecchione A, Croce CM, et al: Integrated microRNA and mRNA signatures associated with survival in triple negative breast cancer. PLoS One 8: e55910, 2013.

47. Augoff K, McCue B, Plow EF and Sossey-Alaoui K: miR-31 and its host gene lncRNA LOC554202 are regulated by promoter hypermethylation in triple-negative breast cancer. Mol Cancer 11: $5,2012$.

48. Humphries B, Wang Z, Oom AL, Fisher T, Tan D, Cui Y, Jiang $Y$ and Yang C: MicroRNA-200b targets protein kinase $\mathrm{C} \alpha$ and suppresses triple-negative breast cancer metastasis. Carcinogenesis 35: 2254-2263, 2014. 